\title{
Koca Râgıb Paşa'nın Şiirlerinde Sebk-i Hindî Tesiri
}

\section{Beyhan KESIK $^{\mathrm{a}}$}

\section{Özet}

Sebk-i Hindî, Türk edebiyatında XVII. yüzyıldan itibaren etkili olmaya başlamış ve her şairin şiirinde ayrı özellikleriyle karşımıza çıkmıştır. Nef'î'de mübalağa, Nâbî'de hikemî ve söylenmemiş yeni manalar şeklinde görülen bu üslup, Koca Râgıb Paşa'nın şiirlerinde tıpkı Nâbî'de olduğu gibi, ilk plânda hikemî mana olarak karşımıza çıkmaktadır. Sebk-i Hindî, Koca Râgıb'ın şiirlerinde hikemî mananın yanı sıra bazı dil ve muhteva özellikleri ile de etkili olmuştur. Bu özellikler, genişletilmiş tamlamalar ve birleşik yapılar, yeni-orijinal kelime ve terkipler/tamlamalar, somutlaştırma ve alışılmamış bağdaştırmalar, konuşma diline ve avâma ait kelimeler, Türkçe dil unsurları yerine Farş̧a dil unsurlarının kullanımı, şiir dilinden sapmalar, mübalağa ve aşırı hayalcilik, örnekleme beyit sistemi, yeni imajlar ve kavramlar şeklindedir.

Anahtar Kelimeler: Sebk-i Hindî, Koca Râgıb Paşa, dil, muhteva, imaj.

\section{Sebk-i Hindi’s Influence On Koca Râgıb's Poems}

\begin{abstract}
Absract
Sebk-i Hindi has started to affect Turkish literature since the 17th century and has been seen as different characteristics on each poet's poems. This style which was seen as exaggeration in Nefi's poems, as hikemi and unvoiced new meanings in Nabi's poems has been seen first as hikemi meaning in Koca Râgıb Pasha's poems just like in Nabi's poems. In addition to hikemi meanings in Koca Râgıb's poems, Sebk-i Hindi has been effective with some language and content features of its. These features are extended phrases and composite structures, new-original words and combinations/phrases, formalizing and unwonted harmonizations, colloquial words, using Persian language components instead of Turkish language components, decline from poetry language, exaggeration and being overmuch unrealistic, sampling verse system, new images and conceptions.
\end{abstract}

Key Words: Sebk-i Hindi, Koca Râgıb Pasha, language, contents, image.

\footnotetext{
${ }^{a}$ Yrd. Doç. Dr., Giresun Üniversitesi ,Fen-Edebiyat Fakültesi,Türk Dili ve Edebiyatı Bölümü b_kesik@hotmail.com/beyhan.kesik@giresun.edu.tr, Giresun.
} 


\section{Giriş}

Safevîlerin dinî ve siyasî baskıları neticesinde İran'da Samanîler döneminden beri edebiyatın gelişmesinde büyük rol oynayan sarayların şairlere kapanması ve dinî edebiyata önem verilmesi gibi iddialar sonucunda ${ }^{1}$ İran'dan kaçıp Hindistan'daki Bâbür İmparatorluğuna sı̆̆ınan Fars şairlerince meydana getirilen Sebk-i Hindî (Hint üslubu), İran'da Sâib-i Tebrizî ile en parlak şeklini almıştır. Bu üslup, İran'da Kelim ve Tâlib dışında fazla sevilmemiş olmasına karşılık, Hindistan ve Afganistan'da çok ilgi toplamış, Divan edebiyatını da XVII. yüzyılın ilk yarısında Nef' ̂́' nin şiirleriyle başlayarak şiddetle etkilemiştir (Ocak, 2002a: 66). Haluk İpekten'in ifadesiyle İran'da doğmuş, Hindistan'da gelişmiş ve XVII. yüzyıldan itibaren Türk edebiyatını etkisi altına almıştır (İpekten, 1987: 70).

Sebk-i Hindî'nin adı, menşei ve ortaya çıkışı ile ilgili çeşitli görüşler ileri sürülmüştür. Bazı araştırmacılar, Sebk-i Hindî yerine, bu şiir tarzını temsil eden şairlerin birçoğunun İsfahan'da yetişmesi dolayısıyla "Sebk-i İsfahan̂̂" tabirini de kullanmışlardır (Bilkan, Aydın, 2007: 14). Hüseyin Sadîk, Sebk-i Hindî'nin menşei olarak Azerbaycanlı şairleri görür ve Sebk-i Azerbaycanî'nin daha sonra gelişerek Sebk-i Hindî olarak meşhur olduğunu söyler. Sadîk daha ilginç bir iddiayla bu üslûbun Türkçe düşünüş tarzı temellerinin Fuzûlî, Fars şiirindeki temellerininse Sâib-i Tebrizî tarafından atıldığını öne sürmektedir (Sadîk, 1370/1990, 20). Ali Fuat Bilkan ve Şadi Aydın, Sadîk'ın hataya düştüğünü belirttikten sonra, Halil Toker'in -Sebk-i Hindî temsilcileri arasında Sâib-i Tebrizî, Şevket-i Buhârî, Bidil ve Mirzâ Gâlib gibi Türk asıllı şairlerin çoğunluğu teşkil etme gerekçesinden hareketle- bu üsluba "Sebk-i Türkî̀" de denilebileceği görüşünü belirtirler.” (Bilkan, Aydın, 2007: 15).

Bu tür gerekçeler, bu üslubun adının Sebk-i Hindî olduğu gerçeğini değiştirmemektedir. Gerçek olan bir şey var ki o da dönemin tezkirecilerinden

\footnotetext{
${ }^{1}$ İranlı şairlerin Hindistan'a gitmelerinin tek sebebini, Safevî padişahların ilgisizliğine bağlamak eksik bir yargı olur. Ancak, Safevî padişahlarının özellikle methiyelere karş1 ilgisiz kaldığı da bir gerçektir. Hele ki Hint-Türk hükümdarının Unsurî'nin bir beytine yüz köle verdiği düşünülürse, İran sarayının bu yarışta ne denli geri kaldığı ortaya çıkar. Hindistan'a yönelmenin arkasında maddî çıkar ve servet biriktirme çabasının yattı̆̆ını ileri süren araştırmacılar, bir bakıma haklıdırlar (Bilkan, Aydın, 2007: 18). Bu araştırmacılardan birkaçı şunlardır: Hindistan'a göçen İranlı şairler hakkında geniş bir araştırma yapan Ahmed Gülçîn-i Me’ânî, Zebîhullâh Safâ (Babacan, 2008: 55).
} 
hiçbirisinin "Sebk-i Hindî" ifadesini kullanmadığıdır. Nasüriddin Şâh Hüseynî, "Sebk-i Hindî" isminin, daha ziyade Afganistan ve Hindistan'da gelişme gösterdiğini belirtir ve bu bakımdan, onu İran'daki şiir üslubundan ayırmak için "Hint" sıfatıyla niteler (Bilkan, Aydın, 2007: 15).

Sebk-i Hindî’nin özelliklerini kısaca şu şekilde sıralamak mümkündür: ${ }^{2}$

$\mathrm{Bu}$ üslupta, şiirin temel iki unsurundan biri olan anlam, diğer önemli unsuru olan söze üstün tutulmuştur. İnce ve yeni manalar bulma düşüncesinin bir gereği olarak da anlam, derin ve girift, ince ve zariftir. Sâib'in "Ince manalar bulmak için kıl gibi inceldim. " ve Şevket'in, anlamın bir hasırın telleri gibi örülmüş, iç içe geçmiş ve girift olması gerektiğini ifade eden sözleri, bu durumu en veciz şekilde dile getirmektedir.

Şiirde anlamın derinliklerde ve girift olması, hayal ve heyecan unsurlarının ön plana çıkmasına, muhayyilenin önem kazanmasına neden olmuş ve dolayısıyla şiirin anlaşılmasını güçleştirmiştir.

\footnotetext{
${ }^{2}$ Sebk-i Hindî’nin özellikleri aşağıdaki çalışmalardan derlenmiştir:

Şener Demirel (2006), 17. Yüzyıl Sebk-i Hindî Şairlerinden Nâilî ve Fehîm'in Şiirlerinde Soyutlama ya da Alışılmamış Bağdaştırmalar, Sözde ve Anlamda Farklılaşma: Sebk-i Hindî, Turkuaz Yay., İstanbul, s. 35-88; Halil Toker (2006), Sebk-i Hindî: Hint Düşünce Tarzının Edebiyata Yansıması ve Urdu Dilindeki Sebk-i Hindî, Sözde ve Anlamda Farklılaşma-Sebk-i Hindî, Turkuaz Yay., İstanbul, s. 155-171; Ömer Okumuș (1989), "Hind Üslûbu (Sebk-i Hindî), Atatürk Üniversitesi Fen-Edebiyat Fakültesi, Edebiyat Bilimleri Araştırma Dergisi, s.107-117; Halil Toker, (1996); "Sebk-i Hindî (Hint Üslûbu), İlmî Araştırmalar, İlim Yayma Cemiyeti, İstanbul, s.141-150; Kamer Aryân (2006), "Fars Şiirinin İçinde Hindî Adıyla Meşhur Üslubun Ortaya Çıkısı ve Özellikleri”, Sözde ve Anlamda Farklılaşma: Sebk-i Hindî, Haz. H. Aynur, M. Çakır, H. Koncu, Turkuaz İstanbul; İsrafil Babacan (2008), Klasik Türk Şiiri'nde Sebk-i Hindî (Hint Üslubu), Yayımlanmamış Doktora Tezi, Gazi Üniversitesi Sosyal Bilimler Enstitüsü Türk Dili ve Edebiyatı Anabilim Dalı Eski Türk Edebiyatı Bilim Dalı, Ankara; Halûk İpekten (1987), Nâilî Hayatı, Edebî Kişiliği ve Bazı Şiirlerinin Açıklanması, Atatürk Üniversitesi Fen Edebiyat Fakültesi Yayınları, Erzurum; Fatma Tulga Ocak (2002b), "XVII. Yüzyıl Şairi Nef'î ve Kaside", Türkbilig TÜRKOLOJİ ARAŞTIRMALARI, Hacettepe Üniversitesi Edebiyat Fakültesi, Sayı 3 s. 63-82); Fatma Tulga Ocak (2002b), XVII. Yüzyılın İlk Yarısında Divan Edebiyatı ve Sebk-i Hindî, Türkler C. 11, Yeni Türkiye Yay., Ankara; Ali Fuat Bilkan (2007), "Orta Klasik Dönem (1600-1700) Şiir", Türk Edebiyatı Tarihi C.II, Kültür ve Turizm Bakanlığı Yay., İstanbul; Ali Fuat Bilkan (2004), "Nazım (Orta Klasik Dönem)", Türk Dünyası Edebiyatı Tarihi C. 5, Atatürk Kültür Merkezi Bakanlığı Yay., Ankara; Cafer Mum (2007), "Orta Klasik Dönem (1600-1700) Sebk-i Hindî", Türk Edebiyatı Tarihi C.II, Kültür ve Turizm Bakanlığı Yay., İstanbul.
} 
İnsan ruhu ve heyecanları üzerine kurulan hayaller derinleştikçe 1stırap, şiirde daha çok yer tutmaya başlamış, ifrat mesabesine ulaşarak bu üslûbun ayırt edici bir özelliği olmuştur.

Karamsarlık ve derin 1stırabın ifadesi ve bunun sonucunda dış dünyadan kaçış, tasavvufa yönelme sonucunu doğurmuştur.

Zihnin, orijinal mana ve hayaller bulmaya zorlanması neticesinde, mübalağa sanatı ön plâna çıkmıştır. Şairler "gulüv" derecesinde mübalağa yapmaktan çekinmemişlerdir. Ancak bunu yaparken, belâgat ve fesahat kaidelerine de uymuşlardır.

Şairlerin eşya ve olaylara - eşyanın ruh sahibi birer varlığa dönüşmesi gibi- farklı yönlerden bakma çabaları, mübalağa sanatının yanı sıra tezat ve teşhis sanatlarını da ön plâna çıkarmıştır.

Yeni mazmunlar bulmak ve daha önce söylenmemiş anlamlar keşfetmek, şairlerin başlıca uğraşı alanı olmuştur. Hayalî kavramların, 1stırabın anlatıldığı yeni mazmunlar şiire sokulmuştur.

$\mathrm{Bu}$ tarz şiirde yeni ve orijinal hayal ve anlam unsurlarını ifade edebilmek için ince, nazik ve süslü bir dil kullanılmış, aynı anlamı veren sözlerden, ince ve zarif olanları, anlama en uygun düşenleri seçilerek alınmıştır. $\mathrm{Bu}$ hususta Şevket'in, "söz ince ve narin bir örtüdür, o kadar ince olmalı ki altındaki anlamı örtmesin” sözü dikkat çekicidir.

Şiir diline yeni giren kelimelerle süslü, bedii bir üslup meydana getirilmiştir. Dolayısıyla bu üslup, muamma ve bilmece gibi anlaşılması ve çözülmesi zor, yapmacık bir şiir tarzı olması bakımından zaman zaman tenkit edilmiştir. $\mathrm{Bu}$ şiir tarzının temsilcilerinin realiteden kopmaları, çevreyi ve sosyal olayları görmezlikten gelmeleri de iyi karşılanmamıştır.

$\mathrm{Bu}$ üslupta kısa fakat özlü anlatımın bir gereği olarak sözü uzatan edebî sanatların kullanımından kaçınılmış, istiare, mecaz-1 mürsel, kinaye, telmih vb. yoğun anlatım imkânı veren sanatların kullanılması yoluna gidilmiştir. Böylelikle söz kısa fakat dolgun söylenmiş, az sözle çok şey anlatılmak istenmiştir. Sebk-i Hindî şairlerinin edebî sanatlara verdiği önemi ifade etmesi bakımından Tâlib-i Âmulî’nin, istiaresiz şiirin tadı tuzu yoktur, sözü dikkat çekicidir.

Sebk-i Hindî şairleri, kendinden önceki şairlerin kelime ve tabirlerini kullanmakla beraber, onlara farklı ve şahsi manalar yüklemişlerdir. Bu şekilde ortaya çıkan "ferdîlik" bu şiir tarzının önemli yeniliklerindendir. 
Sebk-i Hindî şiirinin en önemli nazım şekli kuşkusuz, "gazel"dir. Gazelin ön plana çıkması sonucunda, klasik gazelin konusu olan aşk, sevgili ve şarap gibi konuların yanı sıra, yeni mazmun arama gayreti içerisinde felsefe, hikmet ve öğüt gibi konular da gazele girmiştir.

Hint üslubu, Türk edebiyatında XVII. yüzyıldan itibaren etkili olmaya başlamış ve şairlerin şiirlerinde ayrı nitelikleriyle karşımıza çıkmıştır. Nef' '̂́'de mübalağa, Nâbî'de hikemî ve söylenmemiş yeni manalar şeklinde görülen bu üslup, Nâilî, Neşâtî, Şehrî, Fehim-i Kadim ve İsmetî gibi şairlerde ise anlam derinliği ve orijinal mazmunlarla kendisini göstermektedir (Bilkan, 2007: 267). $\mathrm{Bu}$ üslubun Fars edebiyatındaki iki önemli temsilcisi olan Şevket ve Sâ'ib, Türk şairleri üzerinde oldukça etkili olmuştur. XVII. asırdan itibaren, Türk şiirinde görülmeye başlanan Şevket ve Sâ'ib'in etkisi, XVIII. yüzyılda hemen göze çarpar. Bu etki iki kol halinde yani Nedîm ve Şeyh Gâlib üzerinde Şevket; Nâbî, Râgıb Paşa ve bunların muakkiplerinde Sâ'ib tesiri şeklinde görülür (Köprülü, 2006: 379-380).

Bazı araştırmacılara göre, Hint üslubunun Türk şiirine geçişinde ana kaynak Nâbî'dir. Bu araştırmacılardan Ali Nihat Tarlan, Türk şiirindeki yeniliğin toplu ve şuurlu hamulesinin Nâbî'de görüldüğünü belirttikten sonra, XVI. yüzyıl sonlarına kadar devam eden muayyen klasik müşebbehünbih ve mazmun âleminden, birden bire daha geniş bir realite ve tahassüs âlemine geçildiğini ifade etmektedir (Tarlan 1948, 223). Tarlan'ın bu ifadesi, Hint üslubunun Türk edebiyatına girişinde Nâbî'nin önemini işaret etmektedir. Nâbî'nin, Sebk-i Hindî şairleri içinde en fazla Sâ'ib'den etkilendiği bir gerçektir (Babacan, 2008: 123). Gibb ise Nâbî'yi zamanının Sâ'ib'i olarak nitelendirdikten sonra sözlerine şöyle devam etmektedir:

"Tabiattyla bir Türk de kendine bu şairi üstat tanlyacakt. Zira o, Iran'in ölmekte olan şiirine taze bir hayat getirmek gibi bir kabiliyetin sahibi büyük bir şairdi. Celaleddin'in haleflerinin artık eskimiş tasavvuf felsefesini ve Hafız okulunun bayağılaşmış içki alemleri terennümlerini bir kenara bırakarak Iran şiirinde yeni olan ve büyük bir coşkuyla karşılanan didaktik, hikmetli şiir tarzını işlemiştir" (Gibb, 1999: 222-223).

Hikemî Şiir'in Türk edebiyatında en önemli temsilcisi olan Nâbî'nin XVIII. yüzyılda en önemli takipçisi Koca Râgıb Paşa'nın şiirleri, adeta birer hikmet dükkânı gibidir. Şair, Nâbî'nin yolunda yürümekle Hint üslubunun Sâ'ib kolunun XVIII. yüzyıldaki temsilcilerinden biri olmuştur. Râgıb'ın şiirlerinde 
daha çok hikmetli söyleyiş olarak kendini hissettiren Hint üslubu, muhtelif dil, mana ve muhteva özellikleriyle de kendini göstermektedir.

Bu çalışmada Hint üslubunun Koca Râgıb Paşa'nın şiirleri üzerindeki dil ve muhteva tesirleri, Türkçe divanından hareketle, değerlendirilmeye çalışılacaktır.

\section{Dil Özellikleri}

a. Genişletilmiş Tamlamalar ve Birleşik Yapılar: Sebk-i Hindî şiirinin dili söz konusu edildiğinde, akla ilk gelen özellik muhakkak ki üç veya daha çok unsurdan oluşan karışı genişletilmiş tamlamalar ile iki unsurlu tamlamaların ters çevrilmesinden (izâfet-i maklûb) ya da kısaltılmasından (izâfet-i maktû́') oluşan birleşik yapılardır (Babacan, 2008: 185). Bu yapılar sayesinde Sebk-i Hindî şairleri, derin anlamlar ifade eden şiirler söylemişlerdir. Bu özellikler Râgıb'ın şiirlerinde de mevcuttur. Bunlardan birkaçı şu şekildedir:

Olmadım reh-yâb-ı sırr-ı kâkül-i ham-ber-hamın ${ }^{3}$

Çok kilîd-i müşkili etdim güşâd endîşede $(G .142 / 4)^{4}$

Sâgar-ı telh-âbe-i gam-nûş ${ }^{5}$ ldır meşreb bana

Vâdî-i nâ-kâmıdır muhtâr olan mezheb bana (G. 3/1)

Neşve-i sahbâ-yı hikmet câm-ı endîşemdedir

Cilve-i şûh -ı perî-zâd-ı sühan ${ }^{6}$ şişsemdedir (G. 33/1)

Perde-i nâmûsa girmez berk-i 'âlem-sûz-ı 'aş ${ }^{7}$

Bî-mehâba neşve-i ser-şâr kendin gösterir (G. 36/3)

Hum-ı ser-cûş-ı sahbâ-yı hıred ${ }^{8}$ zarf-ı cünûnumdur

Hikem-âmûz-ı Eflâtûn' 'akl-ı zü-fünûnumdur (G. 42/1)

Verir Cibrîl'e hayret rif'at-ı mir 'âc-l endîşem

Burâk-ı berk-tâz-ı 'akl-ı küll' esb-i harûnumdur (G. 42/4)

\footnotetext{
${ }^{3}$ kıvrım kıvrım olan saçın sırrına vakıf olan

${ }^{4}$ Numaralı beyitler, Ömer Demirbağ'ın Yüzüncü Y1l Üniversitesi Sosyal Bilimler Enstitüsü'nde, 1999 yılında doktora tezi olarak hazırladığı "Koca Râgıb Paşa ve Dîvân-ı Râgıb" adlı çalışmadan alınmış olup gazel için "G.”, kaside için "K." kısaltmaları kullanılmış ve bu kısaltmalardan hemen sonra beyit numaraları belirtilmiştir.

${ }_{6}^{5}$ gam içenin istırap içkisinin kadehi

${ }^{6}$ sözün periden doğmuş şuh cilvesi

${ }^{7}$ aşkın âlem yakan yıldırımı

${ }^{8}$ idrak kadehinin saf şarabi/hum-1 ser-cûş tabirine, Afifi'de (Afifî, 1376/1997: II/1409)

"ser-cûş-1 hum" şeklinde "saf şarap" anlamı verilmiştir.
} 
Kesik, B. / Sosyal Bilimler Araştırmaları Dergisi. 2, (2009): 150-169

Ben ol sihr-âferîn-i fitne-engîzz-i pür-âşûbum ${ }^{10}$

Fesân-ı tîg-ı ebrû-yı bütân ${ }^{11}$ nakş-ı füsûnumdur (G. 42/5)

Anılsun kûşe-i vîrâne-i bît-kaydî̀-i devlet ${ }^{12}$

Ser ü sâmân-ı ârâm ile âbâd oldugum yerdir (G. 47/4)

Biz dürd-nûş-ı mey-kede-i derd-i mihnetiz ${ }^{13}$

Hûrşîd câm-ı bâdemiz olsa sifâl olur (G. 61/3)

Şî̀e-i şûhî̀i 'imâret-i dil ${ }^{14}$

Nigeh-i mest-i pür-âb iledir (G. 65/2)

Sakın ey herze-tâz-ı nev-süvâr-ı eşheb-i devlet ${ }^{15}$

Çıkar elden 'inânın tevsen-i nahvet licâm almaz (G. 79/2)

Tâ bilmedikce kayd-ı rehâdan halâsımız

Magrûr-ı dâm-ı şîve-i sayyâd ${ }^{16}$ olur muyuz (G. 80/3)

Dem-sâz-ı sabâ oldu Rühâvî bize Râgıb

Dil-beste-i zincir-i ser-i zülf-i Rühâyız ${ }^{17}$ (G. 89/8)

b. Yeni-Orijinal Kelime ve Terkipler: Sebk-i Hindî şairlerinin her geçen gün biraz daha artan yeni mazmun, anlam ve hayaller bulma çabası, yerli ve yabancı birçok kelimenin şiir diline girmesine sebep olmuştur (Mum, 2007: 384). Bunun neticesinde Sebk-i Hindî şairleri yeni bir şiir dili icat ederek Hintİran sahası şairlerinden hazır kavramlar ithal etmişler ve bunları şiirlerinde kullanmaktan uzak durmamışlardır.

Hint-İran sahası Sebk-i Hindî şiirinden alınan hazır kavramlar, daha çok kinâye, teşbih ve temsil esasına dayanan edebî ifadelerdir. Bu tür ifadelerin anlaşılması konusunda yapılacak en büyük hata, ifadelerin kelime kelime çevrilmesidir. Oysa doğru olan bu ifadelerin, Hint-İran sahası şairlerinin şiirlerindeki manalarına bakmak ve söz konusu sahada sırf Sebk-i Hindî konusunda yazılan lügatlere müracaat etmektir (Babacan, 2008: 201). Râgıb

\footnotetext{
9 akl-1 küllün hızlı hareket eden Burak'1

${ }^{10}$ karışıklık dolu fitneleri harekete geçiren sihrin yaratıcısı

11 güzellerin kılıç gibi kaşlarının efsanesi

12 talih kayıtsızlığının virane köşesi

${ }^{13}$ Mihnet dertleri meyhanesinde tortu içeniz

14 gönül binasının şuhluk şivesi

15 devlet kır atının acemi süvarisinin saçma sapan sözlerinin koşuşturması

${ }^{16}$ avcının hile tuzağına aldanmış
} 
Kesik, B. / Sosyal Bilimler Araştırmaları Dergisi. 2, (2009): 150-169

Paşa'da az da olsa bu tür kullanımlara rastlamak mümkündür. Bunlardan bazıları şunlardır:

Lenger-i 'akl ile pâa-ber-c $\hat{\boldsymbol{a}}^{18}$ iken mânend-i kûh

Şimdi şûr-ı 'aşka bak deryâ gibi cûş eyledim (G. 111/6)

Fârisî 'arsa-i 'irfân geçinirken şimdi

Yerlere urdu beni tevsen-i baht-ı bed-râm ${ }^{19}$ (K. III/31)

Âlemi eylemişdi dîde-be-râh $\boldsymbol{h}^{20}$

Hasret-i intikâm-ber-i dil-hâh (K. I/9)

Pür-dilân cümle dâg-ber-dil ${ }^{21}$ idi

Ahz-ı sârında pây-der-gil Id $^{22}$ (K. I/8)

c. Somutlaştırma, Alışılmamış Bağdaştırmalar ve Hiss-âmîzî:

Türlü öğretim alanlarında, sık sık başvurulan bir öğretici anlatım biçimi olan somutlaştırma, başka bir ifadeyle alışılmamış bağdaştırmalar (Dilçin, 2009: 131), soyut kavramların somut unsurlar vasitasiyla ifade edilmesidir. Bağdaştırma, tamlama deyim gibi, söz varlığı içindeki öğeleri, tümce ya da sözceleri, anlamlı, kabul edilebilir birimler hâlinde bir araya getirmeye denir. Bağdaştırmalar, alışılmış ve alışılmamış bağdaştırmalar olarak ikiye ayrılmaktadır. Alışılmış bağdaştırma biraz önceki tanımı karşılarken, alışılmamış bağdaştırmalar, anlam belirleyicileri, anlam ayırıcıları arasında uyum bulunmayan birleştirmelerdir (Demirel, 2006: 42). Bu özellik, Sebk-i Hindî'ye mensup olmayan şairlerin şiirlerinde de zaman zaman görülmektedir; fakat, bu üslubun tesirinde olan şairlerin şiirlerinde çoğaldığ 1 ve s1klıkla başvurulduğu müşahede edilmektedir (Deniz, 2006: 98-99). Koca Râgıb Paşa'nın şiirlerinde de yer yer rastladığımız bu tür bağdaştırmalarla, sözü inceltme, az sözle çok şey ifade etme, ince ve derin hayallerle yeni/orijinal mazmunlar ortaya çıkarma gayesi güdülmüştür. Aşağıdaki beyitlerde sırasıyla yer alan "bâzĥu-yı fitne" (fitne bazusu), "meşâm-ı hezâr-arzu" (binlerce arzunun burnu), "zükâm-l visâl" (kavuşma nezlesi), ifadeleri bu tür bağdaştırmalardandır:

17 Urfalı(Nabi)nın saçının ucuna gönül bağlamışız.

${ }^{18}$ kalıcı ve kuvvetli (Afifî, 1376/1997: I/334)

${ }^{19}$ serkeş, huysuz, dik başlı baht (Afifî, 1376/1997: I/225)

${ }^{20}$ dikkatli olmak, intizar ermek (Afifî, 1376/1997: I/225)

${ }^{21}$ hasret, gam ve zorlukta birakmak (Afifî, 1376/1997: II/ 878) 
Kesik, B. / Sosyal Bilimler Araştırmaları Dergisi. 2, (2009): 150-169

Dâg-ı sahtı iken 'âlem o kemân-ebrûdan

Bâzîu-yı fitne anı tarf-ı benâgûşa çeker (G. 48/3)

Olup meşâm-ı hezâr-arzûu zükâm-ı visâl

Henüz ki şemm-i gül-i kâma biz dimâg ararız (G. 83/2)

Aşağıdaki beyitlerde ise, soyut çağrışım unsurları olan "emel, kâm, hüsn, râhat, gam, sevda, dil”; mir'ât ve fülk, sahil, kumaş, bâliş, zehr-âb, leşker, dûd gibi unsurlarla somutlaştırılmıştır:

Dile mir'ât-ı emelden nice sûret görünür

Bilmez ammâ ki verâsında vehâmet görünür (G. 37/1)

Varır mı sâhil-i kâma dökündü vermeyicek

Bu yemde fülk-i emel bâr-ı bî-hesâb döker (G. 53/5)

Kumâş-ı hüsne eger gerd-i hattı verdi kesâd

Dahı metâ'-ı gurûru girân-bahâda gezer (G. 40/2)

Hicr-i gül-i ruhsârl ile bâliş̧-i râhat

Bir pûte-i hâr olmadadır derd-i serimden (G. 125/4)

Elinden çekdigim sâkî-i dehrin nîş ü semdir hep

Benim sahbâ diyü nûş itdigim zehr-âb-ı gamdır hep

(G. 13/1)

Sevâd-ı leşker-i sevdâ serinde dûd-ı dil çetri

Gedâyân-ı ser-i kûy-ı muhabbet muhteşemdir hep (G. 13/2)

Sebk-i Hindî şairlerinde, somutlaştırmaların alışılmamış bağdaştırmalarla birleşerek oluşturduğu özel bir bağdaştırma türüne de rastlanır. Hint-İran sahası Sebk-i Hindî şiirinde hiss-âmîẑ (hislerin karışması) adı verilen bu tabir, Türkçemizde duyular arası geçiş olarak adlandırılabilir (Babacan, 2008: 221).

Koca Râgıb Paşa aşağıdaki beyitte, "sükût-ı cân-güdâz-ı nâz" (nazın can yakan/eriten sessizliği) tabiriyle dokunma ya da görme duyusuna ait yanma özelliğini işitme duyusuna ait sessizlik ile ifade etmiştir:

Beni hem-şu 'le-i âvâz-ı bülbül eyleyen Râgıb

Sükît-ı cân-güdâz-ı nâz, ile ol gonce-femdir hep (G. 13/7)

${ }^{22}$ sakin ve hareketsiz olmak, incinmiş ve dertli olmak (Afifî, 1376/1997: 355) 
Aşağıdaki beyitlerde ise "çeşm-i gûyâ" (konuşan göz) ve "sürme-i $\hat{a} v a \hat{z}-\imath$ bî-dârî-i baht" (bahtımın uyanıklık çığlığının sürmesi, siyahlığı) terkipleriyle de işitme duyusuna ait bir özellik görme duyusuna atfedilmiştir:

Biri bîm ü biri ümmîd ile etdi kebâb âhir

Figân dest-i leb-i hâmûşdan evvel çeşm-i gûyâdan (G. 119/3)

Sürme-i âvâz-ı bîdârî-i bahtımdır benim

Ol siyehkârî-i müjgânın ki hâb olmuş sana (G. 4/3)

d. Konuşma Diline Yer Verme ve Avâma Ait Tabirler: Koca Râgıb Paşa, Klasik Türk şiirinin XVIII. yüzyıldaki genel eğilimine bağlı olarak konuşma dili özellikleri, mahallî unsurlar ve avâma ait tabirleri şiirinde çokça kullanmıştır. Bu kullanımlar, bazen bir deyim, bazen ikileme, bazen ünlem, bazen ses taklidi, bazen de redif olarak şiirin tamamına yayılmaktadır. Bunlardan birkaçı şu şekildedir:

Kapagı Şâma atmakdır dil-i şûrî̀denin fikri

Rehâ bulsa eger zincir-i zülf-i şûh-l şeydâdan (G. 119/9)

Hayli demdir atdı tutdı zülf-i dil-berden sabâ

Sen de var 'uşşâk içün bir tâze tel ey şâne at (G. 19/2)

Zahm-ı hadeng-i gamzesi cân u cigerdedir

Göz degmesin efendi meded gizli yerdedir (G. 29/1)

Efendi kanlı bıçaklıdır câm-ı sâkî ile

Ne oldu zâhide şimdi enîs ü hem-demdir (G. 56/2)

Bir âh-ı huşk ise işin Allaha kaldı bil

Hiç kûy-ı yâre nâme-berin yok mudur senin (G. 106/2)

Sevâd-ı perde-i hatta tevârî itme 'illetle

Kıyâmet kopsa geçmez yek-ser-i mû dil o sevdâdan (G. 119/4)

Hâh Misr u hâh Bagdâd iş̧te şehbâ işte Şâm

Var mıdır İstânbulun mümtâz u müstesnâları (G. 171/6)

e. Cümlede Farsça Dil Unsurlarının Türkçe Dil Unsurlarının

Yerine Kullanımı: Sebk-i Hindî döneminden önce de görülen bu özellik, Sebki Hindî şairlerinde gözle görülür bir şekilde artmıştır. "Üslûp bilimi açısından, üslûp tespitini kolaylaştıran söz konusu durum, dil gelişimi açısından sağlıklı sayılamaz. Cümle sentaksında Farsça unsurların ağırlık kazanması yine, başta Hint-İran sahasından hazır kavramlar almak ve Farsça cümle sentaksının Türkçe 
cümle yapısında (hazf, eklerden tasarruf vs.) kısaltmaya neden olan etkilerinden dolayı tercih edilmiştir." (Babacan, 2008: 266).

Bu söyleyiş özelliğinin Râgıb'ın şiirlerinde de önemli bir yere sahip olduğu gözlemlenmektedir. Ancak, bu durum Sebk-i Hindî’ye ait olmayıp yukarıda da belirtildiği gibi sayıca artışı bakımından dikkat çekicidir. Râgıb, ne zamana kadar soru zarfinı, Farsça şeb-tâ-seher (geceden sabaha kadar) ve nereye kadar soru zarfını da Farsça şark-tâ-garb (doğudan batıya kadar) şeklinde -e hâl ekini Farsça "-tâ" ekiyle karşılamakla oluşturmuştur:

Tâbiş-i fikr-i ruhuyla ol bütün şeb-tâ-seher

Külbe-i şevkımda rûşen revgân-ı gülden çerâg (G. 98/5)

Nice feth-i cedîde mazhar ola

Şark-tâ-garb ana musahhar ola (K. I/20)

Yukarıdaki örneklere benzer kullanımların "-tâ" ekiyle birlikte "-be" ekinin birleştirilmesi suretiyle de oluşturulduğu gözlemlenmektedir. Bunlardan bazıları şunlardır: tâ-be-nâf (göbeğine kadar), ser-tâ-be-pâ, ser-tâ-be-kadem (baştan ayağa kadar):

Mest olup etmiş girîbânin güşâde tâ-be-nâf

Vaktidir ol mâh ile istersen olmak sîne-sâf (G. 99/1)

Hâhiş-i dilden sadâ-yı gonce-i peykânına

Gül gibi ser-tâ-be-pâ her zahmımı gûş eyledim (G. 111/4)

Ser-tâ-be-kadem gül gibi ol gûş̧-ı hakîkat

Bülbülden işit nâliş-i hayret neye derler (G. 62/2)

Şu beyitlerde kullanılan "pâ(y)-der-gil" (sakin, hareketsiz, incinmiş ve dertli olmak), "dâg-ber-dil" (gamlı olma, hasret ve zorlukta birakma), "'lydber-bâlâ-yı "yyd" (bayram bayram üstüne), "dâg-ber-bâlâ-yı dâg" (yara yara üstüne), "tekellüf-ber-taraf" (aradaki resmiyeti kaldırma), "dest-ber-kemer" (hazır bekleme), "hâk-ber-ser" (yerle bir etme), "nâ-be-hengâm" (zamansız) gibi durum zarfları hâl ekleriyle beraber tamamıyla Farsça dil kaidelerine uygun olarak teşkil edilmiştir:

Cûları pâ-der-gil etdi bülbül-i gûyâyı lâl

Bâg-ı hüsnün cünbiş-i serv-i semen sîmâları (G. 171/2)

Kemâlinden degildir dâg-ber-dil kimseye kimse

Medâr-ı hıkd u kîn gavgâ-yı dînâr ü dirhemdir hep (G. 13/6)

Böyle zâtın müsned-i fetvâyı teşrîf etmesi 
Kesik, B. / Sosyal Bilimler Araştırmaları Dergisi. 2, (2009): 150-169

Oldu erbâb-ı kemâle 'yyd-ber-bâlâ-yı 'yyd (K. V/9)

Dâg-ı nevdir raks-ı mâh üzre kelef zan eyleme

Eyledi hüsnün sipihri dâg-ber-bâlâ-yı dâg (G. 98/4)

Saf-ı çîn-i cebîne böyle tâb-âver midir diller

Cesâretle tekellüf-ber-taraf imdâd-ı gamzendir (G. 38/4)

'Aceb mi hayret ile dest-ber-kemer olsa

Şu bezm-i bî-mezenin vaz'ına seb̂̂larımız (G. 90/3)

İdersin hâk-ber-ser hânümân-ı zühd ü takvâyı

Gel ey burc-l şehâmet zûr-l meyden böyle bel verme

(G. 140/3)

Iztırâb-ı nâ-be-hengâm istemez tahsîl-i kâm

Mevki inde bî-tekellüf kâr kendin gösterir (G. 36/2)

2.2. Mana ve Muhteva Özellikleri: Hint üslubunun asıl önemli özelliği, mana üzerine bina edilmiş olmasıdır. Belâgat ve fesahat kurallarının her zaman daha önemli kabul edildiği klâsik şiir anlayışının aksine, bu şiir anlayışında mana ön plâna alınmıştır (Bilkan, Aydın, 2007: 132-133). Sebk-i Hindî şairlerinin peşinden koştuğu mana, yeni mazmunlar ve yeni hayallerle ifade edilmiştir. Klâsik tarzda kullanılan klişeleşmiş mazmunları büyük oranda terk eden şairler, bunların yerlerini alabilecek yeni mazmunlar ibda edebilmek için olağanüstü bir çaba sarf etmişlerdir. Yeni mazmun arayışında olan şairler, dikkatlerini tabiata ve topluma çevirmişlerdir (Mum, 2007: 389). Başka bir ifadeyle şairler, "mânâ-yı bîgâne",23 peşinde koşmuşlardır.

Sözü mümkün olabildiğince kısa tutma ve az sözle çok şey anlatma düşüncesinde olan Sebk-i Hindî şairleri, anlamın tamamını yalnızca bir beyitte, hatta bir mısrada toplayabilmek için sözü uzatan lafzî sanatlardan uzak durmuşlar, teşbih, istiare, telmih ve kinaye gibi sözü kısaltma özelliği bulunan sanatları fazla kullanmışlardır (Mum, 2007: 388).

$\mathrm{Bu}$ üslûpta duygunun yerine akla önem verilmesinin bir sonucu olarak gücünü şairlerin kendi şahsî gözlemlerinden ve hayat tecrübelerinden alan hikmet, asıl konusu aşk ve rintlik olan gazelin aslî konularından biri hâline gelmiştir (Mum, 2007: 385). Fars şiirinde Sâib-i Tebrizî, Türk şiirinde ise XVII. yüzyılda Nabi ve XVIII. yüzyılda Koca Râgıb Paşa bu hikemî tarzın en önemli

\footnotetext{
${ }^{23}$ Bîgâne mana, başkasına görünmeyen manadır (Babacan, 2008: 100).
} 
uygulayıc1ları olmuşlardır. Dolayısıyla "Nabi'de hikemî ve söylenmemiş yeni manalar şeklinde görülen bu etki" (Bilkan, 2007: 266), Koca Râgıb Paşa'da da benzer etkiler şeklinde karşımıza çıkar. "Râgıb Paşa'nın şiirleri sağlam ve ahenkli bir nazma, ağırbaşlı, seçkin ve açık bir söyleyişe, insanı düşünce yoluyla saran hikmetli bir muhteva özelliğine sahiptir."(Kesik 2009). ${ }^{24}$

a. Sebk-i Hindî'nin hikemî muhteva dışında Râgıb'ın şiirlerine tesirlerinden biri de -kısmen de olsa- mübalağa ve aşırı hayalcilik şeklindedir.

Aşağıdaki beyitlerde sırasıyla, güneşin kadehe benzetilmesi, sonra bu güneş kadehinin testi gibi değersiz kabul edilmesi, kurt ile kuzunun dost olması, vücutta meydana gelen yaraların ay ışı̆̆ının fitilinden daha parlak olması, ölmeye güç kalmaması, güzelliğin güneşe 1şık kaynağı olması gibi garip hayallerle yüklü mübalağalar içermektedir:

Biz dürd-nûş-l meygede-i derd-i mihnetiz

Hûrşîd câm-ı bâdemiz olsa sifâl olur (G. 61/3)

Pâsbân-ı re'se hulk olalı insâfi

Gürg ile eylediler 'akd-ı uhuvvet agnâm (K. III/24)

Ne hâcet pertev-i dil-sûz-ı yârân-ı bî-mihre

Olur dâgım fitîl-i penbe-i meh-tâbdan rûşen (G. 127/2)

Etdi ten-i nizârımı feryâd u nâle hâl

Kaldım o rütbe za 'file yok irtihâle hâl (G. 108/1)

Tâb-ı şikest-i leşker-i zulmet muhâl idi

Hüsn olmasaydı pençe-i hûrşîde fer veren (G. 128/6)

b. Sebk-i Hindî'nin muhteva özelliklerinin Râgıb'ın şiirlerine örnekleme beyit sistemi (üslûb-1 muâdele) şeklinde de yansıdığını söylemek mümkündür. ${ }^{25}$

\footnotetext{
${ }^{24} \mathrm{Bu}$ çalışmada, Koca Râgıb Paşa'nın şiirlerine Sebk-i Hindî’nin hikemî muhteva dışındaki tesirleri üzerinde durulduğundan, Paşa'nın şiirlerindeki hikemî muhtevaya temas edilmedi. Koca Râgıb Paşa'nın şiirlerindeki hikemî muhteva özellikleri için şu çalışmaya bakılabilir: Beyhan Kesik, "Koca Ragıb Paşa'nın Şiirlerinde Hikemî Tarz" Uluslar Arası V. Klâsik Türk Edebiyatı Sempozyumu, 16-18 Ekim 2009, Mardin (Basılmamış Bildiri).

25 İran sahasında bir şekil özelliği taşıyan bu nitelik, şiirin muhtevasına katkısı nedeniyle Osmanlı sahası Sebk-i Hindî şiiri araştırmalarında bir muhteva özelliği olarak kabul edilmiştir (Babacan, 2008: 447).
} 
Sebk-i Hindî şiirinde gazel -daha önce de değindiğimiz gibi- şairlerin en fazla ilgi gösterdiği nazım şekli olmuş, kafiye veya kafiye-redif bağları ile birbirine bağlanan "tek beyit"ler üzerine kurulmuştur. Bu tek beyitlerin özel bir yapısı vardır. "Kedkenî tarafından "üslûb-ı muadele" olarak adlandırılan bu özel yap1, bir beyti oluşturan misraların gerek gramer gerekse anlam bakımından birbirinin tamamen bağımsızlığını esas almaktadır." (Mum, 2007: 386). Türk şiirine, Sebk-i Hindî yoluyla girmeyen, ancak Sebk-i Hindî şairlerince ustalık ve sıklıkla kullanılarak yeni manalar ile mazmunlar bulmada bir vasıta olarak kullanılan bu beyit yapısı, bir mısrada ifade edilen herhangi bir soyut düşüncenin, diğer mısrada gözlem ve deneyime dayanan başka somut bilgiyle örneklendirilmesine imkân sağlamaktadır. Soyut düşüncenin dile getirildiği mısraa "mısra-ı makûl" veya "pîş-mısra" somutlaştırmanın yapıldı̆̆ 1 diğer misraa ise "mısra-ı mahsûs" veya "mısra-ı berceste" denmektedir. Mısralar arasındaki ilişki teşbih, temsil, leff ü neşr, hüsn-i ta'lil gibi sanatlarla kurulabilmektedir. Özellikle teşbih, mısralar arasındaki ilişkiyi sağlayan en önemli unsurdur. Böyle bir durumda, soyut düşüncenin anlatıldığ $\mathrm{m} ı$ sra/pîşmısra, benzeyen; gözlem ve deneyime dayalı somut bilginin verildiği diğer mısra, mısra-1 mahsûs/mısra-1 berceste ise benzetilen olmaktadır (Babacan, 2008: 316; Mum, 2006: 122).

Aşağıdaki beyitte birinci mısra, mısra-1 makûl/pîş-mısra, ikinci mısra ise misra-1 mahsus/mısra-1 bercestedir. Pîş-mısradaki kelimelerin mısra-1 mahsusta somutlaştırıldığ 1 hemen görülecektir. Şair, kelâli/bıkkınlı̆̆1 hâba/uykuya, zühhâdı/ham sofuları kec-nazarâna/kıskançlara, hüsnü/güzelliği de kitaba benzetmekle anlatmak istediklerini somutlaştırmış, böylelikle okuyucuyu ikna etme ve anlattıklarını okuyucunun zihninde canlandırma yolunu seçmiştir:

Kelâl verdi temâşâ-yı hüsnü zühhâda

'Aceb mi kec-nazârâna getürse hâb kitâb (G. 12/2)

(Zâhitlere güzelliği seyretmek usanç ve bıkkınlık verdi. Kitap okumak, eğri bakışlılara/hata arayanlara uyku verse şaşılır mı?)

Koca Râgıb Paşa'nın şiirlerinde dikkati çeken üslûb-1 muâdele tarzında söylenmiş beyitlerden birkaçı şunlardır:

Kendi 'aybindan olur rûy-nümâ 'ayb-kesân

Olsa âyine şikeste olur endâm şikest (G. 18/3) 
Kesik, B. / Sosyal Bilimler Araştırmaları Dergisi. 2, (2009): 150-169

(Kusurlu kimselerin kusurları, kendi yaptıklarından anlaşılır. Ayna kırık olunca yansıması da kırık olur.)

Olan hem-vâr-l tıynet ıztırâb etmez havâdisden

Ki hâmûn eylemez pâ-mâlî-i seyl-âbdan feryâd (G. 25/2)

(Yaradılışı düzgün olanlar başa gelenlerden incinmez. Çünkü, bozkır sele maruz kalmakla feryat etmez.)

Olayım kayddan âzâde diyen kayda düşer

Deliden uslu haber nâle-i zencîr verir (G. 27/5)

(Bağdan/endişeden kurtulayım diyen kişi yine bağa/endişeye düşer. Deliden en doğru haberi zincir sesleri verir.)

Giryedir mâye-i teskîn-i gubâr-ı hâtır

Gerd çıksa felege nâzil olur reş basılır (G. 30/4)

(Gönül tozunun teskinlik mayası ağlamaktır. Toz, göğe çıksa da yağmurla birlikte aşağı iner.)

Pest-fitratlara zînet ile rif'at gelmez

Olsa her tarz ile kalîçe münakkaş basılır (G. 30/2)

(Alçak yaradılışlı kimselere süs, yücelik vermez. En küçük, en basit halı bile nakışlı olur.)

Eylemez îrâs-ı hüsn ârâyişi bed-tıynetin

Zînet olmaz mâra endâmındaki nakş u nigâr (G. 57/4)

(Yaratılışı kötü olanların süsü, onlar için güzellik sebebi olmaz. Yılana üzerindeki şekiller süs olmaz.)

Pîc ü tâb-ı sîneden efkâr kendin gösterir

Cevher-i âyîneden jengâr kendin gösterir (G. 36/1)

(Sıkıntılı gönülden, fikirler meydana çıkar; aynanın pası da cevherinden meydana gelir.)

Hûb u zişt âsârıdır âyîne-i girdâr-ı halk

Her ne sûret tarh eder sehhâr kendin gösterir (G. 36/6)

(Halkın gidişatını yansıtan ayna güzellik ve çirkinlik eserleriyle doludur. Sihirbaz, oyunu hangi şekilde ve nasıl düzenlerse düzenlesin, yine kendini öne çıkararak hokkabazlığını gösterir.)

Tecellî neş'esin ehl-i şikem idrâk kâbil mi

Behişt andıkca zâhid ekl ü şürbün lezzetin söyler (G. 36/8) 
(Dünyaya midesinden bağlı kimselerin tecellî neşesini anlaması mümkün mü? Zâhit, cenneti ve cennet nimetlerini andıkça, daima oradaki yeme içmenin lezzetini söyler.)

Meyân-ı güft u gûda bed-meniş îhâm eder kubhun

Şecâ' 'at 'arz ederken merd-i kıbtî sirkatin söyler (G. 39/5)

(Kötü huylu kimseler, dedi kodu yaparken kendi çirkinlik ve kötülüklerini hatırlatırlar. Çingene, kahramanlık göstereyim derken kendi hırsızlığını söyler.)

Derd ü gamdan ıztırâb etmez hevâvî-meşrebân

Keștîye bâr-ı girân bâ is-i temkîn olur

(İsteklerinin peşinden koşan kimse dertten ve gamdan incinmez. Gemiye ağır yük, temkinli gitme nedeni olur.)

İmtiyâz-ı sâbit ü seyyârı müşkildir hayâl

Zan eder sükkân-ı keştî sâhil-i deryâ yürür (G. 46/3)

(Hareketli ve hareketsiz nesnelerin tamamen ayırt edilmesini hayal etmek güçtür. Geminin üzerindekiler, gemi hareket ettikçe sahilin yürüdüğünü sanırlar.)

Sâf ttynet sâf dillerden mükedderdir yine

Hâtır-ı âyinede âb u hevâdandır gubâr (G. 57/6)

(Yaratılışı saf/temiz olanlar yine gönlü temiz olanlardan incinir. Aynanın üzerindeki toz, su ve havadandır.)

Feyz-i Hakdır eserin bâ 'isi esbâb degil

Dest-i cinnîde nigîn mühr-i Süleymân olmaz (G. 91/2)

(Bir eserin ortaya çıkmasının nedeni sebepler değildir, Allah'ın feyzidir. Yüzük, cinin elinde Hz. Süleyman'ın mührü olmaz.)

Mâye-i feyz verir revnâkl zînet vermez

Zîver-i cevher ile rûşen olur mu kandîl (G. 110/4)

(Parlaklığı/güzelliği bilgi verir, süs vermez. İçindeki süsle kandil ışık vermez.)

c. Sebk-i Hindî’nin Râgıb'ın şiirleri üzerindeki tesirlerinden biri de ateş ve Musa-Tûr-tecellî gibi, bazı önemli imajlar ve kavramlar şeklindedir.

Sebk-i Hindî şairlerinin, gerek beşerî aşkın halleri olduğu düşünülen durumlarda gerekse tasavvufî aşkın boyutlarını tasvir ettikleri şiirlerinde en çok kullandıkları hayal ve imajlardan biri "ateş"tir. ${ }^{26}$ Koca Râgıb Paşa da, iç

\footnotetext{
${ }^{26}$ Sebk- Hindî'de ateş imajı için bakınız (Babacan, 2008: 379-384).
} 
dünyasındaki yanışın bir hezeyanı olarak sevgilinin ayrıllı̆ında dış dünyaya bir ateş yumağından bakar ve gözlemlediği her nesnede -tıpk1 Şeyh Gâlip gibi- ${ }^{27}$ ateşi görür. Şair, aşağıda iki beytini verdiğimiz "sensiz" redifli gazelinde birtakım somutlaştırmalarda ve benzetmelerde "ateş" imajını en veciz şekliyle kullanmıştır. Sevgilinin hayaliyle ayrılık gecesinde, gönüldeki hasretle şairin ah fidanı, ateşler yağdıran bir fidandır. Böyle bir ruh hâliyle şair, çiy tanesini kıvılcım, gülü ateş, serkeş serviyi/sevgiliyi şu'le/parıltı, sümbülü duman olarak görmektedir:

Şeb-i firkat tecellî-zâr-ı hasretdir hayâlinle

Nihâl-i medd-i âhım nahl-i âteş-bârdır sensiz (G. 81/2)

Şerer şebnem gül âteş serv-i ser-keş şu'le sünbül dûd

Ser-â-pây gülistân 'ayn-ı âteş-bârdır sensiz (G. 81/3)

Sebk-i Hindî şairleri tarafından, özellikle Tûr ${ }^{28}$ ağacı ve tecellînin çeşitli hâlleri, sevgili ve aşkın hâllerinin benzetileni olarak kullanılmıştır. Buna benzer kullanımlara Râgıb Paşa'nın şiirlerinde de rastlamak mümkündür. Şair, güzelliğin tecellî ettiği yerin kimseyi bu güzellikten mahrum bırakmayacağını, dağın hareketlerinden sevgilinin/Allah'ın kendini göstereceğini ifade ederken Allah'ın Tûr Dağı'ndaki tecellîsini ifade etmektedir:

Kimseyi mahrûm-ı feyz etmez tecellî-zâr-ı hüsn

Cünbiş-i kûhsârdan dîdâr kendin gösterir (G. 36/4)

Aşağıdaki beyitte ise, ayrılık gecesinde hasret tecellisiyle yanarak ah eden gönle her şey, adeta ateş yağdıran bir fidan olmaktadır. Buradaki fidanla da Tûr Dağı'nda Musa'nın ateş gördüğü ağaca işaret edilmektedir:

Şeb-i firkat tecellî-zâr-ı hasretdir hayâlinle

Nihâl-i medd-i âhım nahl-i âteş-bârdır sensiz (G. 81/2)

\section{Sonuç}

Râgıb Paşa'nın şiirlerinde Sebk-i Hindî tesiri öncelikle hikmetli mana olarak görünmüştür. Hikmetli söz söylemenin dışında Koca Râgıb Paşa'nın

\footnotetext{
${ }^{27}$ Ateş imajını en iyi ifade eden şiirlerden biri Şeyh Gâlip'in "âteş" redifli gazelidir. Bu gazel ve izahı hakkında bilgi için bakınız (İpekten, 1991: 107-112).

${ }_{28}$ Mûsâ'nın ilahî hitâbı işittiği ve “tecellî̀”nin gerçekleștiği yer olan Tûr, tasavvufta gönle işaret eder. Klasik şiirde gönül, Tûr Dağı'na benzetilerek tecellî edilen mahal olduğu anlatılır. Mûsâ, Tûr ve tecellî kelimeleri tenasüp içinde ele alınır (Üstüner, 2007: 189). Tûr tasavvufta ayrıca, insanın maddî yapısını da temsil eder. Nitekim bu maddî
} 
şiirlerinde Sebk-i Hindı̂’nin bazı dil ve mana özelliklerini gözlemlemek mümkündür.

Koca Râgıb Paşa'nın şiirlerinde yer alan Sebk-i Hindî şiirinin dil özelliklerini şu şekilde özetlemek mümkündür:

Sebk-i Hindî’nin önemli dil özelliklerinden olan üç veya daha çok unsurdan oluşan karışık genişletilmiş tamlamalar ile iki unsurlu tamlamaların ters çevrilmesinden (izâfet-i maklûb) ya da kısaltılmasından (izâfet-i maktû‘) oluşan birleşik yapılara çokça başvurulmuştur.

Hint-İ́ran sahası Sebk-i Hindî şiirinden alınan pâ-ber-câ gibi hazır kavramlara yer verilmiştir.

Sebk-i Hindî şiirinin önemli dil özelliklerinden olan somutlaştırmalar ve alışılmamış bağdaştırmalar ile bunların birleşerek oluşturduğu özel bir bağdaştırma türü olan ve Hint-İ́ran sahası Sebk-i Hindî şiirinde hiss-âmîzî (hislerin karışması) adı verilen duyular arası geçişin örneklerine yer verilmiştir.

Klasik Türk şiirinin XVIII. yüzyıldaki genel eğilimine de bağlı olarak konuşma dili özellikleri olan mahallî unsurların ve avâma ait tabirlerin çokça kullanılmasına mukabil, Türkçe dil unsurları yerine Farsça dil unsurlarına da hemen aynı oranda ilgi gösterilmiştir.

Sebk-i Hindî şairlerinde sıkça görülen şiir dilinde sapmaların örneğine az da olsa rastlanmaktadır.

Sebk-i Hindî’nin dil özelliklerinden başka bazı muhteva özelliklerinin de Koca Râgıb'ın şiirlerine etki ettiği gözlemlenmiştir. Bu özelliklerin başında, hikmet gelmektedir. Muhteva özelliği olarak hikemî mana dışında -kısmen de olsa- mübalağa ve aşırı hayalcilik vardır.

Râgıb'ın şiirlerinde muhteva özelliği olarak dikkati çeken hususlardan biri de, Türk şiirinde Sebk-i Hindî'den önce de var olan; fakat, bu üslûbun şairlerince sıkça başvurulan üslûb-1 muâdele/örnekleme beyit sistemidir. Şair, düşüncelerini, irfan ve halk hikmetine dayanan özlü sözlerini örnekleme beyit sisteminin etkileyici ve pekiştirici özelliğinden bolca istifade ederek dile getirmiştir.

Sebk-i Hindî'nin Râgıb'ın şiirleri üzerindeki tesirlerinden biri de ateş ve Musa-Tûr-tecellî gibi, bazı önemli imajlar ve kavramlar şeklindedir.

yapı, Allah'ın tecellîsi ile yok olur. Bunun için önce varlığı yok etmek gerekir (Pala, 1998: 401). 
Sözün özü, Koca Râgıb Paşa, şiirlerinde Sebk-i Hindî’nin bazı dil ve muhteva özelliklerinin tesirinde kalmış ve bu özelliklerden bazılarına çok, bazılarına da az yer vermiştir. Ancak, Sebk-i Hindî’nin dil özellikleri, mana ve muhteva özelliklerine oranla daha belirgindir. Bu özelliklerden dolayı Koca Râgıb Paşa'ya doğrudan Sebk-i Hindî şairi demek yerine, onun bu üslûbun bazı dil ve muhteva özelliklerinin tesirinde kalmış bir şair olduğunu söylemenin daha doğru olacağ kanaatindeyiz.

\section{Kaynakça}

Babacan, İ. (2008), Klasik Türk Şiiri’nde Sebk-i Hindî (Hint Üslubu),Yayımlanmamış Doktora Tezi, Gazi Üni. Sos. Bil. Ens., Ankara.

Bilkan, A. F. (2004). "Nazım (Orta Klasik Dönem)”, Türk Dünyası Edebiyatı Tarihi C. 5, Ankara: Atatürk Kültür Merkezi Başkanlığı Yayınları

Bilkan, A. F. (2007). “Orta Klasik Dönem (1600-1700) Siir”, Türk Edebiyat1 Tarihi C.II, İstanbul: Kültür ve Turizm Bakanlığı Yayınları

Bilkan, A. F.; AYDIN, Ş. (2007). Sebk-i Hindî ve Türk Edebiyatında Hint $\quad$ Tarzı, İstanbul: $3 \mathrm{~F}$ Yayınevi

Demir, S. (2006), “Tecellî’nin İki Beyti Üzerinde Sebk-i Hindî ile İlgili Yorumlar", Sözde ve Anlamda Farklılaşma: Sebk-i Hindî (Haz. H. Aynur， M. Çakır， H. Koncu), İstanbul: Turkuaz Yayınları

Demirbağ, Ö. (1999), Koca Râgıb Paşa ve Dîvân-1 Râgıb (Yüzüncü Yıl Üniversitesi Sosyal Bilimler Enstitüsü Basılmamış Doktora Tezi), Van.

Demirel, Ş. (2006), "17. Yüzyıl Sebk-i Hindî Şairlerinden Nâilî ve Fehîm'in Şiirlerinde Soyutlama ya da Alışılmamış Bağdaştırmalar", Sözde ve Anlamda Farklılaşma-Sebk-i Hindî (Haz. H. Aynur, M. Çakır, H. Koncu), İstanbul: Turkuaz Yayınları

Dilçin, C. (2009), "Divan Şiirine Stilistik Yaklaşım", Uluslararası Türk Dili ve Edebiyatı Kongresi, C. 2 (Bildiriler-Türk Edebiyatında Üslûp Arayışları), İstanbul Kültür Üniversitesi Yayınları: 121-137

Gibb, E. J. W. (1999). Osmanlı Şiir Tarihi, C. III-IV (Çev. Ali Çavuşoğlu), Ankara: Akçă̆ Yayınları

Hüseyin Muhammedzâde Sadîk (1370/1990), Şerh-i Gazelhâ-yı Sâib-i Tebrizî, Tahran: İntişârâtî-i Elest

İpekten, H, (1987), Nâilî Hayatı, Edebî Kişiliği ve Bazı Şiirlerinin Açıklanması Erzurum: Atatürk Üni. Fen Edebiyat Fakültesi Yayınları

İpekten, H, (1991), Şeyh Gâlib, Edebî Kişiliği ve Bazı Şiirlerinin Açıklanması, Erzurum: Atatürk Üni. Fen Edebiyat Fakültesi Yayınları 
Kesik, B. / Sosyal Bilimler Araştırmaları Dergisi. 2, (2009): 150-169

Kamer Aryân (2006), "Fars Şiirinin İçinde Hindî Adıyla Meşhur Üslubun Ortaya Çıkısı ve Özellikleri”, Sözde ve Anlamda Farklılaşma, Sebk-i Hindî (Haz. H. Aynur, M. Çakır, H. Koncu), İstanbul: Turkuaz Yayınları

Kesik, B. (2009), "Koca Râgıb Paşa'nın Şiirlerinde Hikemî Tarz" Uluslar Arası V. Klâsik Türk Edebiyatı Sempozyumu (Basılmamış Bildiri), Mardin.

Köprülü, F. (2006), Divan Edebiyatı Antolojisi (Yay. Haz., Ahmet Mermer), Ankara: Akçağ Yayınları

Mum, C. (2007), "Orta Klasik Dönem (1600-1700) Sebk-i Hindî”, Türk Edebiyatı Tarihi C.II, İstanbul: Kültür ve Turizm Bakanlığı Yayınları

Mum, C. (2006), "Sebk-i Hindî’de Beyit Yapısı, Paradoksal İmajlar ve Çoklu Duyulama”, Sözde ve Anlamda Farklılaşma: Sebk-i Hindî (Haz. H. Aynur, M. Çakır, H. Koncu), İstanbul: Turkuaz Yayınları

Ocak, F. T. (2002a), “XVII. Yüzyıl Şairi Nef’î ve Kaside”, Türkbilig Türkoloji Araştırmaları, Hacettepe Üni. Edebiyat Fakültesi, S.3: 63-82

Ocak, F. T. (2002b), "XVII. Yüzyılın İlk Yarısında Divan Edebiyatı ve Sebk-i Hindî”, Türkler C. 11, Ankara: Yeni Türkiye Yayınları

Okumuş, Ö. (1989), "Hind Üslûbu (Sebk-i Hindî), Atatürk Üni. Fen-Edebiyat Fakültesi, Edebiyat Bilimleri Araştırma Dergisi: 107-117.

Pala, İ. (1998), Ansiklopedik Divan Şiiri Sözlüğ̈̈, İstanbul: Ötüken Yayınları

Rahim Afifî (1376/1997), Ferheng-name-i Şiirî, C. 2, Tahran: İntişarat-1 Surûş

Tarlan, A. N. (1948), "Şehrî”, IÜEF Türk Dili ve Edebiyatı Dergisi, C. II, S. 3- 4: 225.

Toker, H. (1996), "Sebk-i Hindî (Hint Üslûbu), İlmî Araştırmalar, İlim Yayma Cemiyeti, İstanbul: s.141-150.

Toker, H. (2006), "Sebk-i Hindî: Hint Düşünce Tarzının Edebiyata Yansıması ve Urdu Dilindeki Sebk-i Hindî”, Sözde ve Anlamda Farklılaşma: Sebk-i Hindî (Haz. H. Aynur, M. Çakır, H. Koncu), İstanbul: Turkuaz Yayınları

Üstüner, K. (2007), Divan Şiirinde Tasavvuf, Ankara: Birleşik Yayınları. 